\title{
MEDIADOR CULTURAL OU ANTROPÓLOGO DO MAL: BRUCE ALBERT E O CASO DE "A QUEDA DO CÉU"
}

\section{CULTURAL MEDIATOR OR ANTHROPOLOGIST OF EVIL: BRUCE ALBERT AND THE CASE OF "THE FALL OF HEAVEN"}

Karla Alessandra Alves de Souza Ferreira'

RESUM0:Este estudo desenvolve uma análise crítica sobre o fragmento "Postscriptum, quando eu é um outro (e vice-versa)", apresentado na obra $A$ Queda do céu: palavras de um xamá yanomami. O livro foi pensado por um xamá yanomami; Davi Kopenawa, e produzido por um etnólogo francês Bruce Albert. Problematizo o processo de produçáo do livro onde dois universos culturais se encontram, uma produção literária indígena do povo Yanomami que apresenta uma coautoria. Essa análise busca investigar a postura epistêmica de Bruce Albert como mediador cultural ou "antropólogo do mal" no processo de elaboração do livro, a fim de levantar questionamentos sobre o ato tradutório e suas implicaçóes, destacando os desafios e contribuições apresentadas nesse processo. Nesta direçáo, esse artigo se fundamenta nos pensamentos da história cultural.

PALAVRAS-CHAVE: intelectual mediador, apropriação cultural, história Yanomami.

ABSTRACT: This study develops a critical analysis on the fragment "Postscriptum: when I am another (and vice versa)", introduced in the work "The Fall of Heaven: words of a Yanomami shaman" The book was thought by the Yanomami shaman, Davi Kopenawa, and produced by the French ethnologist, Bruce Albert. I problematize the book producing process, in which two cultural universes meet, an indigenous literary production of the Yanomami people, that presents a co-author. This analysis aims to investigate the epistemic posture of Bruce Albert as cultural mediator or "anthropologist of evil" in the book-making process, in order to raise questions about the translation act and its implications, highlighting the challenges and contributions presented in this process. In this direction, this article is based on the cultural history thoughts.

KEYWORDS: intellectual mediator, cultural appropriation, Yanomami history.

\section{INTRODUÇÃO}

A lógica colonial de enunciação sobre os povos indígenas é algo que sempre questionei ao longo de meus estudos e em minha prática como professora de História da rede pública do Estado de Goiás. O processo de invisibilidade violenta contra os povos indígenas é algo que

Mestranda em História pelo PPGH da Universidade Federal de Goiás (UFG) e bolsista Capes. E-mail: angoladekiaia@gmail.com 
vem sendo alimentado pela ciência eurocêntrica que tradicionalmente percebe os indígenas como objeto de estudo situado num passado cristalizado, construído pela visão eurocêntrica de mundo que nega a contemporaneidade indígena. É, assim, este posicionamento ético e político que motiva as reflexóes aqui apresentadas.

Desde a colonizaçáo Europeia no Brasil até a primeira metade do século XX, os grupos indígenas foram mantidos em uma condição de subalternidade na dinâmica social brasileira.

É notório que a temática indígena percorre a literatura brasileira desde suas primeiras manifestaçôes. No período colonial as descrições iniciais figuram o índio como bárbaro, primitivo, exótico ou puro, dependendo dos interesses que estivessem em voga: exploratórios, religiosos ou políticos. De acordo com Martins, "no século XIX, durante o periodo romântico, com a necessidade da formação de uma identidade nacional, o indigena adquiriu o status na literatura de "bom selvagem", segundo a concepção de Rousseau (2016, p. 121). Foi dessa forma idealizado e caracterizado como portador das particularidades pertencentes aos cavaleiros medievais como a bondade, a coragem a honra e a nobreza.

Na primeira geração do Modernismo, com Oswald de Andrade, Mário de Andrade e Raul Bopp, por meio do Movimento Pau-Brasil e Antropofágico, desenvolveu-se uma crítica à colonizaçáo e à defesa de uma independência mental brasileira. $\mathrm{O}$ índio, autêntico e nacional, foi celebrado em contraposiçáo aos valores europeus. Trata-se ainda de uma idealização, diferente da romântica, mas que vê positivamente o índio na medida em que o dota de uma consciência crítica que é fruto de outra tradição cultural (PEREIRA, 2002).

Na quarta geração do Modernismo desaparece tanto o índio idealizado negativamente pelos românticos, como aquele ideário positivo cultivado pelo modernismo primitivista. Depois dos anos 1970, revela-se um novo olhar, no qual as comunidades indígenas aparecem retratadas por uma perspectiva simultaneamente jornalística e antropológica. O tom é de denúncia acerca do genocídio e do etnocídio vivenciado pelos povos indígenas (OLIVEIRA, 2005, pp. 95-103).

De acordo com Almeida: "ésomente na década de 1980 que começamos a ver as primeiras produçôes de autoria nativa no Brasil" (2008, p. 19). Dentre estes novos autores encontramos Olívio Jekupé, Eliane Potiguara, Graça Graúna, Daniel Munduruku, Luiz Karai, Giselda Jera, Kerexu Mirim, dentre outros. De acordo com Daniel Munduruku (2008), estas produçóes de origem nativa são literaturas de ficção baseadas em sua experiência na aldeia e os memorialistas que escrevem a partir da vivência de sua gente.

Na segunda metade do século XX, ocorreram transformaçóes sociais que favoreceram os povos indígenas brasileiros. Os mesmos passaram a ser sujeitos de políticas indigenistas, as quais buscavam defender as características nativas da sua cultura, fundamentada na oralidade. Com a Constituiçáo Federal de 1988, esses povos obtiveram o reconhecimento dos seus direitos representados pela preservação dos seus costumes, da sua organização social, da garantia da educação básica em sua língua materna e dos direitos originários sobre a terra que ocupavam (FRANCA, 2016, p. 14).

A esse respeito consultar LEOPOLDI (2002, pp. 158-182). 
Nesse contexto, segundo Franca, a educação escolar indígena passava por outro momento de compreensão e interpretação. Com o Decreto n. ${ }^{\circ} 26,{ }^{3}$ aprovado em 4 de fevereiro de 1991, o MEC; Ministério da Educação, passou a estruturar as ações referentes à educaçáo escolar indígena em todos os níveis e modalidades de ensino, em colaboração com a FUNAI; Fundação Nacional do Índio (2016, pp. 14-15).

Foi também elaborado o Referencial Curricular Nacional para as Escolas Indígenas, ${ }^{4}$ com o propósito de assegurar uma educação escolar diferenciada que colaborasse para a afirmação étnica e cultural, direcionada pelo reconhecimento das línguas nativas e dos saberes milenares desses povos. Esta ação teve ainda como objetivo oferecer subsídios para a formação de educadores indígenas capazes de assumir essas tarefas (FRANCA, 2016, p. 15).

Como relata Franca: "a demanda por materiais didáticos e paradidáticos a serem utilizados pelas escolas nas aldeias foi o passo inicial para os autores indigenas" (2016, p. 15). No entanto, a produçáo bibliográfica destes grupos se diversificou quanto ao seu propósito inicial, a fim de assumir outras formas de expressão, e atualmente compreende diferentes gêneros textuais como poesia, contos literários, textos informativos, históricos, entre outros.

Dentre as suas diferentes formas, a autoria pode assumir caráter individual ou coletivo, de acordo com a atuação dos sujeitos envolvidos no processo criativo. A prática da escrita nas sociedades indígenas apresentou-se como alternativa de manutençáo da memória do grupo, um canal de comunicação com outros grupos sociais e, posteriormente, como ferramenta de resistência cultural.

Considerando o tempo histórico, para Franca: "a produção bibliográfica dos povos indigenas pode ser descrita como um fenômeno relativamente recente para a realidade brasileira" (2016, p. 15). Entretanto, o crescente número de autores e publicaçôes evidenciam não só a força criativa desses povos, como também sua habilidade em se apropriar de elementos culturalmente característicos de outros grupos em benefício próprio. Neste ponto, o benefício direto a que se faz referência é a utilização da linguagem escrita, como meio de comunicação com as parcelas não indígenas da sociedade civil.

Ao falarmos de autoria indígena destacamos o livro A Queda do Céu: palavra de um xamã yanomami, publicado originalmente em francês no ano de 2010, na prestigiosa coleção Terre Humaine. A tradução em inglês foi publicada pela Harvard University Press em 2013. No Brasil a obra foi lançada pela editora Companhia das Letras em setembro de 2015, após cinco anos de seu lançamento na França.

BRASIL, Decreto n. 26, de 4 de fevereiro de 1991. Dispóe sobre a Educação Indígena no Brasil, 1991.

BRASIL, Ministério da Educação. Referencial curricular nacional para as escolas indígenas. Brasília: MEC/SEF, 1998 a. Disponível em: http://www.ufpe.br/remdipe/imagens/documentos/edu_escolar/ml_07.pdf. Acesso em 28 abril.2017. 
Colocam-se algumas questóes: sendo Kopenawa ${ }^{5}$ um brasileiro, seu livro não foi lançado primeiro no Brasil por quê? O livro se apresenta como uma coautoria e foi escrito a partir das palavras de Davi Kopenawa Yanomami, contadas a um etnólogo francês, Bruce Albert. Assim, pode-se indagar quais os desafios ou empecilhos encontrados no Brasil para que o livro de Kopenawa e Albert fossem lançados primeiro na França?

Ao refletirmos sobre o processo de tradução de $A$ Queda do Céu, nos deparamos com muitas inquietaçóes. Uma delas é como esse produto cultural pode desafiar os discursos hegemônicos e náo os reforçar? É possível a tarefa que Albert se propôs ao traduzir e montar o livro, objetivando dar voz a história do xamã Yanomami?

Spivak questiona "a posiçâo do intelectual pós-colonial ao explicitar que nenhum ato de resistência pode ocorrer em nome do subalterno sem que esse ato esteja imbricado no discurso hegemônico"(2010, p. 12). Dessa forma, a autora desvela o lugar incômodo e a cumplicidade do intelectual que julga poder falar pelo outro e, por meio dele, construir um discurso de resistência.

Nesta direção, analiso o fragmento "Postscriptum, quando eu é um outro (e viceversa)", apresentado na obra A Queda do céu, onde o antropólogo Albert descreve os processos de mediaçáo que dá origem a obra. O livro foi pensado por um xamá yanomami Davi Kopenawa e produzido pelo etnólogo francês Bruce Albert. Problematizo o processo de produção do livro onde dois universos culturais se encontram por meio de uma coautoria. Essa análise busca investigar o papel do etnólogo Bruce Albert como mediador cultural ou antropólogo do mal no processo de elaboração do livro, a fim de levantar questionamentos sobre o ato tradutório e suas implicaçóes destacando os desafios e contribuiçóes apresentadas nesse processo para o fim do silenciamento epistêmico indígena. Nesta direção, esse artigo se fundamenta nos pensamentos da história cultural.

\section{POSICIONAMENTO TEÓRICO - METODOLÓGICO}

Ao analisar o papel do etnólogo Bruce Albert como mediador cultural ou antropólogo do mal no processo de elaboração e produção do livro $A$ Queda do Céu, esse artigo se fundamenta nos pensamentos da história cultural.

O estudo proposto se fundamenta nos conceitos discutidos na história cultural, como ela se interessa pelas operaçóes de apreensão da realidade social, priorizando os sentidos assumidos por essa realidade em função dos pontos de vista de seus sujeitos históricos, ou seja, das percepçóes cognitivas e afetivas desses sujeitos. Para Chartier: "a história cultural, tem por principal objeto identificar o modo como em diferentes lugares e momentos uma determinada realidade social é construida, pensada, dada a ler" (1987, pp. 16-17). As lutas

Davi Kopenawa nasceu por volta de 1956, em Marakana, grande casa comunal situada na floresta tropical de piemonte do alto rio Toototobi, no norte do estado do Amazonas, próximo à fronteira com a Venezuela. Desde 2004, é presidente fundador da associação Hutukara, que representa a maioria dos Yanomami no Brasil. 
de representaçôes têm tanta importância como as lutas econômicas para compreender os mecanismos pelos quais um grupo impóe ou tenta impor, a sua concepção do mundo social, valores e domínios. Segundo Pesavento; "as representaçóes são matrizes geradoras de condutas e práticas sociais, dotadas de forças integradoras e coesivas, bem como explicativa do real. Individuos e grupos dáo sentido ao mundo por meio das representaçóes que constroem sobre a realidade" (2005, p. 39).

De acordo com GOMES e HANSEN (2016, p. 13): "a história cultural prioriza as preocupaçóes com as dinâmicas de produçâo dos bens culturais, sendo, portanto, fundamental atentar para os fenômenos de sua mediação"s. Ao analisar o processo de produçáo da obra A Queda do céu, por meio da problematização do fragmento: "Postscriptum": Quando eu é um outro (e vice-versa). Buscamos compreender como o etnólogo francês relata o desafio do processo de escrita da obra, destacando o pacto político e "literário" que acordou com o xamá yanomami para o desenvolvimento do livro e suas particularidades como: os bastidores da primeira pessoa, a fabricação do texto entre gravações, transcrição, tradução e a montagem e composição do mesmo. Chartier acredita que há uma série de interpretaçóes e apropriações que fazem com que seja necessário fazer uma história destas formas de leitura. Relata ainda: "a leitura não é somente uma operação abstrata da ação de entender: é pôr em jogo o corpo; é inscrição num espaço; relação consigo e com o outro" (CHARTIER, 2002 , p. 181). Nesse sentido, a apropriação seria a maneira pela qual o indivíduo recebe as condicionantes do meio social e as interpreta, norteando posteriormente suas açóes. De acordo com GOMES e HANSEN:

Os significados e valores atribuídos aos bens culturais, no marco do conceito de apropriação, podem ser encontrados no processo de produçáo - o qual, vale lembrar, também resulta de apropriaçấo da parte de seus produtores -, nas "senhas" por eles inscritas, que devem funcionar como chaves de interpretação, e, finalmente, na sua apropriação pelo receptor "final", sendo assim, eminentemente, mutantes e múltiplos (2016, p. 15).

Os estudos de recepção cultural reforçam a ideia de que ao insistir que "não há sujeito ou público passivo [...] o receptor nada passivo, é um sujeito que, simultaneamente, pode aderir e subverter os sentidos de uma mensagem", por estratégias de seleção de uso, dialogando na maioria das vezes sem saber, com as intençóes dos criadores (GOMES; HANSEN, 2016, pp.15-16).

O antropólogo Albert trabalha com o conhecimento oral do povo yanomami transformando-o em escrita, que vem da oralidade yanomami para a escrita na língua francesa. Esse processo de tradução cultural se faz muito delicado quanto ao sentido e recepçáo dessa obra. Como mediador cultural, Albert ressignifica e se apropria da epistemologia yanomami passada por Kopenawa, cujo objetivo é contar a história de seu povo aos "brancos". Como afirma SPIVAK (2010, p.17): "não são os corpos de sentido que são transferidos nas traduçôes", mas sim a linguagem e seu papel para um determinado agente.

Segundo conceito discutido por Martín Barbero: "As mediações passam a ser transformação do tempo e do espaço a partir de dois grandes eixos, migraçóes, fluxos de imagens e, como consequência as duas mediaçóes fundamentais para pensar o processo de mutação cultural são, para ele, a identidade e a tecnicidade" (2009, p. 14). 
Ao questionar a necessidade desse "agenciamento" apresentado em $A$ Queda do Céu entre o xamã yanomami Kopenawa e o antropólogo Albert, nos perguntamos: a qual representação esse livro serve? Sua construção de sentido inova ou reafirma os lugares de poder da escrita hegemônica? Como relata MIGNOLO (2008, p. 253).

Em primeiro lugar, é necessária a descolonização epistemológica, para em seguida passar para uma nova comunicação inter-cultural a um intercâmbio de experiências e de significaçóes, com a base de outra racionalidade que possa afirmar com legitimidade alguma universalidade [...].

Segundo GOMES e HANSEN (2016, p. 9): "as práticas de mediação cultural podem ser exercidas por um conjunto diversificado de atores, cujas presença e importância nas várias sociedades e culturas têm grande relevância, porém, nem sempre reconhecimento". Tais mediadores não são identificados e nem tão pouco se identificam pela categoria de intelectual. Os intelectuais têm um processo de formação e aprendizado, sempre atuando em conexóes com outros atores sociais e organizaçóes intelectuais ou não, tendo intençóes e projetos no entrelaçamento entre o cultural e o político. Nessa acepção, o conceito de intelectual é como todos os conceitos políticos e sociais, fluído e polissêmico (KOSELLECK, apud GOMES; HANSEN, 2016, p. 12).

Há uma busca de conceitos e categorias para compreender as práticas e meios comunicativos envolvidos na produçáo cultural. Assim como nos respectivos produtos, o caso fornece em particular essas explanaçóes quando se quer observar sua ocorrência entre sujeitos pertencentes a diferentes matrizes culturais (GOMES; HANSEN, 2016, p. 16). Na interpretaçáo crítica desse processo vai se configurando o chamado intelectual mediador, o qual não deve ser entendido como um mero transmissor, isto é, aquele sujeito que não agrega valor ao produto cultural em questão. Segundo GOMES e HANSEN:

O intelectual que atua como mediador cultural produz, ele mesmo, novos significados, ao se apropriar de textos, ideias, saberes e conhecimentos, que são reconhecidos como preexistentes. Com esses outros sentidos inscritos em sua produção, aquilo que o intelectual "mediou" tornase, efetivamente, "outro produto": um bem cultural singular (2016, p. 18).

O intelectual mediador de nossa análise é um antropólogo francês Bruce Albert, nascido no Marrocos, em 1952. É doutor em antropologia pela University de Paris X-Nanterre e pesquisador sênior do Institut de Recherche pour le Développement (IRD, Paris). Participou em 1978 da fundação da ONG Comissáo Pró-Yanomami (CCPY), que conduziu com Davi Kopenawa uma campanha de catorze anos até obter em 1992, a homologação da Terra Indígena Yanomami.

Assim clivamos algumas inquietações relacionadas ao desenvolvimento e o resultado final que é o livro $A$ Queda do Céu. Experimento de coautoria, onde temos um xamá yanomami que quer e precisa falar sobre a história de seu povo e um antropólogo francês que aceita a empreitada dessa mediação cultural, buscando dar voz a Kopenawa yanomami.

Qual o papel desse mediador cultural para a descolonização epistemológica da história do povo yanomami? Ao produzir um bem "cultural singular" nos moldes eurocêntricos, Albert possibilita a articulação de um discurso de resistência ao povo yanomami? 
Devemos ressaltar que A Queda do Céu foi escrito a partir das palavras de Davi Kopenawa Yanomami, contadas a um antropólogo com quem nutre uma longa amizade, foram mais de trinta anos de convivência entre os signatários e quarenta anos de contato entre Bruce Albert, o etnólogo-escritor, e o povo de Davi Kopenawa, o xamá-narrador.

O livro é estruturado em três pilares: a vocação de xamã desde a primeira infância, fruto de um saber cosmológico adquirido graças ao uso de potentes alucinógenos, é o primeiro dos três pilares. O segundo é o relato do avanço dos brancos pela floresta e seu cortejo de epidemias, violência e destruição. Por fim, os autores trazem a odisseia do líder indígena para denunciar a destruição de seu povo.

A análise aqui abordada se desenvolve a partir da leitura do livro $A$ Queda do Céu com delimitação de parte dessa obra, que se configura em "Postscriptum": Quando eu é um outro (e vice-versa), em que Albert relata o desafio do processo de escrita da obra destacando o pacto político e "literário" que deu origem ao livro.

Os bastidores da primeira pessoa, a fabricação do texto entre gravaçôes, transcrição e tradução e a montagem e composição do mesmo foram selecionadas após minuciosas horas de leituras interpretativas do livro de Kopenawa, com o objetivo de problematizar os caminhos percorridos pelo antropólogo Albert nesse experimento de traduçáo como mediador cultural ou antropólogo do mal, ao se enveredar nesse experimento de transcrição e tradução, o antropólogo busca dar voz ao xamã yanomami, entretanto, SPIVAK, "alerta para o perigo de constituir o outro e o subalterno apenas como objetos de conhecimento por parte de intelectuais que almejam meramente falar pelo outro" (2010, p. 13).

\section{ANÁLISE E DISCUSSÃO}

A interpretação proposta do livro $A$ Queda do Céus e pauta no elemento do texto Postscriptum: Quando eu é um outro (e vice-versa), no qual Albert nos explica os primeiros passos de seu itinerário como etnólogo, tendo como objetivo principal apresentar o contexto em que foi registrado e redigido o depoimento excepcional de Kopenawa. Segundo Albert:

[...] Espero que esses modestos fragmentos de "ego-história" contribuam para esclarecer, tanto possível, as situaçóes e peripécias que levaram o nosso encontro, as afinidades que condicionaram a escuta apaixonada que devotei a suas palavras e ainda escolhas que orientaram sua restituição na forma escrita (2015, p. 513).

Os caminhos percorridos para esse experimento de mediação cultural vão se configurando na medida que Albert, por meio do pacto etnográfico, ${ }^{7}$ busca e firma um caminho de realização desse projeto. Como relata Albert (2015, p. 521):

\footnotetext{
Em um artigo publicado anos atrás, Albert define ali o que chama de pacto etnográfico. O "pacto" começa pelo respeito aos três imperativos básicos de todo engajamento do antropólogo com um povo indígena: "Em primeiro lugar, evidentemente, fazer justiça de modo escrupuloso à imaginaçáo conceitual de [seus] anfitrióes; em seguida, levar em conta com todo o rigor o contexto sociopolítico, local e global, com o qual sua [deles] sociedade está confrontada; e, por fim, manter um olhar crítico sobre o quadro da pesquisa etnográfica em si” (1997, p. 520).
} 
O etnógrafo deve estar preparado para compreender que o objetivo principal dos seus interlocutores indígenas e o fundamento de sua cooperação é o de converte o pesquisador em um aliado político, em seu representante diplomático ou intérprete junto à sociedade de onde ele provém, invertendo assim, tanto quanto possível, os termos da "troca desigual subjacente à relação etnográfica”.

Segundo Viveiro de Castro: "a obra A Queda do céu, teve a capacidade de abrir uma fenda na muralha dialógica erguida entre índios e brancos” (2015, p. 33). A formaçáo teórica de Albert, sua "curiosidade intelectual" de base 'estruturalista', é responsável pela sintonização do ouvido analítico do antropólogo na frequência de onda da imaginaçáo conceitual de Kopenawa.

Temos um intelectual mediador, que após ganhar confiança dos yanomami, imbricase na imensa tarefa de começar a avaliar sua aptidão para servir de intermediário na comunicação entre dois mundos. O material etnográfico registrado a partir de então é ao mesmo tempo o alicerce e o produto desse pacto.

Ao oferecerem seu saber ao etnógrafo Albert, o povo yanomami aceita a incumbência de ressocializá-lo numa forma que lhes parece mais adequada à condição humana. Ao procurar o antropólogo Albert para escrever um livro sobre a história do povo yanomami, Kopenawa demonstra a dificuldade de falar e ser ouvido, assim recorre ao discurso hegemônico para fazê-lo. De acordo com Albert, para o povo yanomami as palavras escritas são:

Os Yanomami chamam as páginas escritas e, de modo mais geral, os documentos impressos contendo ilustraçôes (revistas, livros, jornais) de utupasiki ("peles de imagens"). Para o papel, utilizam a expressão papeosiki, "peles de papel”. Referem-se à escrita com termos que descrevem certos motivos de sua pintura corporal: oni (séries de traços curtos), turu (conjunto de pontos grossos) e yáikano (sinusoides). Escrever é, assim, "desenhar traços”, “desenhar pontos” ou "desenhar sinusoides", e a escrita, tRê ã oni, é um "desenho de palavras"(2015, p. 610).

A história do povo Yanomami ${ }^{8}$ há muito tempo já vem sendo escrita por antropólogos europeus e norte-americanos. Um livro recente, Yanomamö: The Fierce People (Yanomamö: O Povo Feroz), de Napoleon Chagnon, causou um grande impacto entre os Yanomami e a ciência ocidental, uma vez que o antropólogo construiu uma imagem sensacionalista do povo, descrevendo-o como "manhoso, agressivo, e intimidador", "feroz", "guerreando continuamente entre si", e vivendo em um "estado de guerra crônica" (TIERNEY, 2002, p. 416).

Chagnon afirmou no artigo" Life histories, blood revenge, and warf are in a tribal population", publicado pela revista Science em 1988, que dentro da sociedade Yanomami, aqueles membros que praticaram algum tipo de assassinato têm maior facilidade para conseguir parceiras sexuais. Segundo ele, "em muitas sociedades, atingir o sucesso cultural parece levar ao sucesso biológico (genético)". Yanomamö: the fierce people vendeu desde seu primeiro lançamento, em 1970, mais de um milhão de cópias.

8 "Yanomami" é uma simplificação do etnômio Yanómami, termo que, seguido do plural tëpë, significa "seres humanos" em yanomami ocidental (KOPENAWA; ALBERT, 2015, p. 609). 
Um dos aspectos a serem destacados na análise foi o fato de que os Yanomami reais náo participaram dos debates acerca de seu próprio povo. A repercussão se deu muito mais por conta da briga entre os antropólogos Napoleon Chagnon, Jared Diamond e Steven Pinker que sustentam em suas teses o mito do "selvagem brutal" contra Kenneth Good, Marhall Sahlins, Philippe Decola que condenam as caracterizaçóes de Chagnon sobre os Yanomami.

O documentário "Segredos da Tribo" de José Padilha, produzido para a BBC inglesa e a HBO americana, em janeiro de 2010, expõe de forma inédita as entranhas deste universo, tanto os resultados desastrosos que provocaram estas pesquisas realizadas em território venezuelano, quanto a brutal troca de ofensas e acusaçōes entre diferentes antropólogos formados pelas melhores universidades do mundo (STYCER, 2010).

Há também um relato autobiográfico importante, o de Helena Valero, cativa dos Yanomami durante 24 anos. O livro Yanoama descreve as experiências de uma menina brasileira capturada pelos índios aos treze anos, em 1932, numa época em que os guerreiros yanomami lutavam para expulsar os coletores de produtos da floresta que estavam invadindo suas terras. A história foi editada pelo biólogo italiano Ettore Biocca em 1965.

Historicamente os povos indígenas foram alvo de diferentes percepçôes e julgamentos referentes a seu comportamento e forma de lidar com o mundo, foram assim caracterizados a uma totalidade homogênea a partir da visão etnocêntrica predominante no mundo ocidental europeu.

Conforme Mignolo: "no processo de desenvolvimento da "consciência moderna de tempo", as sociedades "atrasadas" são aquelas que não respondem aos estilos e exigências dos modos de vida europeus (2010, p. 64). Assim, a invenção do "primitivo" e da "tradiçáo" foram os primeiros passos para traduçáo contemporânea de povos e áreas subdesenvolvidas. Como descreve Baniwa:

[...] Dessa visão limitada e discriminatória, que pautou a relação entre índios e brancos no Brasil desde 1500, resultou uma série de ambiguidades e contradiçôes ainda hoje presentes no imaginário da sociedade brasileira e dos próprios povos indígenas. A sociedade brasileira majoritária, permeada pela visão evolucionista da história e das culturas, continua considerando os povos indígenas como culturas em estágios inferiores, cuja única perspectiva é a integração e a assimilação à cultura global. Os povos indígenas, com forte sentimento de inferioridade, enfrentam duplo desafio: lutar pela autoafirmação identitária e pela conquista de direitos e de cidadania nacional e global (2006, p. 34).

Diante do exposto, analisamos fragmento "Postscriptum": Quando eu é um outro (e vice-versa), de um livro que nasceu no decorrer de diferentes episódios que marcaram a luta em defesa dos direitos yanomami nas décadas de 1980 e 1990, que formando entre Davi Kopenawa e Bruce Albert, a estima e a cumplicidade que constituem a base do projeto que desembocou na redaçáo deste livro. "O Postscriptum retraça a história do pacto entre o coautor e Davi Kopenawa que desembocou neste livro; rememora

"Descreve o povo Yanomami como agressivo, intimidador, "feroz", guerreando continuamente entre si, e vivendo em um "estado de guerra crônica” (CHAGNON, 1968, p. 37). 
(memorializa) as peripécias de uma vocação e as vicissitudes de uma pesquisa de campo realizada, em larga medida, durante os negros tempos de nossa ditadura militar" (CASTRO,2015, pp. 28-29).

No ano de 1989, Davi Kopenawa envia 03 fitas gravadas para o etnólogo Albert, onde fazia um relato angustiado em sua língua, das doenças, mortes, da violência e estragos provocados pela cobiça desenfreada dos garimpeiros. No final, segundo Albert: "o xamá yanomami pedia que eu o ajudasse a divulgar suas palavras. A gravaçáo dessa mensagem me parece ser, retrospectivamente, o evento fundador que selou entre nós o pacto político e "literário" que deu origem a este livro" (2015, p. 531).

Assim várias entrevistas foram traduzidas em textos e publicados na França e no Brasil, sobre a situação do povo yanomami, o impacto da divulgação desses primeiros ensaios políticos-xamânicos a quatro máos, fez com que Kopenawa "pedisse a Albert para ir além dos trabalhos de pesquisa costumeiros e ajudá-lo a transformar suas palavras em um livro" (2015, p. 532).

No começo de 1993, a toque de caixa, a redação de um primeiro manuscrito, a partir de quinhentas páginas de transcrições ( 43 horas de gravação) com a necessidade de aprofundar e suprir lacunas e esclarecer determinados pontos cronológicos, biográficos ou etnógrafos, Albert reinicia a pesquisa abrindo uma linha de entrevistas sobre vocação e iniciaçáo no xamanismo yanomami, enquanto isso, continuava publicando, conforme as demandas e os eventos indigenistas, várias traduçóes de trechos das falas de Davi Kopenawa, isso já nos anos 1990.

Sobre esse novo momento da pesquisa resultam daí como descreve Albert: "sem contar as notas documentais, mais de seiscentas novas páginas de transcrição (cinquenta horas de gravaçáo) que, juntando-se ao corpus anterior, me obrigaram a reformular completamente o manuscrito inicial” (2015, p. 533). A interpretação e os processos de articulaçáo e complexidade através do ato tradutório em que o antropólogo Albert se propôs nos leva a pensar sobre a história da prática tradutória.

Interpretar, implica uma posição diferente do tradutor (ORDINE, 2009).O intérprete deve levar em conta a descrição do processo, no qual o texto da cultura original é reinterpretado, manipulado e até mesmo subvertido quando incorporado na cultura do Centro; e a possibilidade de uma metodologia na qual o significado possa ser trabalhado sem a usurpação da funçáo significativa - proveniente da cultura da qual o texto emergiu (lembrando que essa própria cultura não é uma cultura homogênea, mas sim fruto de um processo de hibridismo).

Esses pontos podem ser melhor clarificados conforme colocações de Said: o oriente é um espaço imaginário construído por uma ideologia, segundo as normas da cultura do ocidente, i. e., "na imaginary geography "where the Orientis orientalized", pictured as it ought to be, rather as it actuallyis" $(1979,67)$. Logo, o oriente é criado, ou orientalizado, fazendo com que haja coincidência das ideias ocidentais sobre o oriente.

De acordo com Ordine: "para evitar essa posição de homogeneidade, o olhar postcolonial, [...] utiliza-se de vozes postcolonial que tentam re-escrever sua história, como 
também mostrar sua posição no contexto do cânone ocidental” (2009, p. 3). Tudo isso sendo confrontado com os tópicos da tradução cultural.

Segundo Burke, a expressão "tradução cultural" foi cunhada por antropólogos do círculo de Edward Evans Pritchard ${ }^{10}$ para descrever o que ocorre em encontros culturais quando cada lado tenta compreender as açóes do outro (2009, p. 14). Nesse trecho, o etnólogo Albert descreve sobre o processo de transcrição e tradução da obra:

\begin{abstract}
A tradução justalinear integral de todas as transcriçôes na ordem das gravaçōes mais de mil páginas teria sido tarefa demasiadamente desgastante. Resolvi, portanto, traduzir as sessôes temáticas indexadas à medida que se mostravam pertinentes no fluxo de minha redação, fundindo as diferentes versôes dos mesmos relatos e comentários, de modo a tornar o texto ao mesmo tempo mais denso e mais conciso. Ao longo desse trabalho de tradução e condensação, respeitei sempre a proposta de me manter o mais próximo possível da fala de Davi Kopenawa. Mas estava fora de questáo propor uma traduçáo palavra por palavra, que, em nome da exatidáo, teria desembocado não apenas na produçấo de um texto totalmente ilegível como também na inadmissível folclorização de sua palavra. Meu conhecimento da língua e da sociedade yanomami já era, na época em que redigi a primeira versão do manuscrito, bastante aceitável para um branco[...] Além de nossas relaçôes de amizade, desenvolvi uma grande familiaridade com o modo de falar característico de Davi Kopenawa, que escutei durante centenas de horas dedicadas à transcrição meticulosa de nossas conversas. Essa bagagem permitiu que eu me considerasse autorizado a propor uma tradução de seu testemunho situada "a meio caminho"11 entre uma literalidade que poderia tornar-se caricatural e uma transposição literária que se afastaria demais das construçôes da língua yanomami (2015, pp. 544-545).
\end{abstract}

De acordo com Burke: "os tradutores têm seus próprios fins que podem deferir daqueles do escrito original e que mesmo quando os tradutores tentavam ser neutros, a língua que utilizava não era" e o autor adverte sobre o fato de que "algo é sempre perdido" (2009, p. 46). A fim de problematizar sobre o processo de transcrição e tradução do livro A Queda do Céu, seguiremos com algumas questões: quem traduz? Com que intensão? $\mathrm{O}$ que? Para quem? De que maneira? Com que consequência? (BURKE, 2009, p. 17).

Os "Bastidores da primeira pessoa" é o título dado ao momento que Albert descreve a estratégia de escrita adotada no livro, que foi escrito por iniciativa de seu narrador, Davi Kopenawa, que o assinou como primeiro coautor. A divisáo do trabalho entre narrador e redator foi, além disso, claramente definida e acordada.

A redação do texto é produto de uma longa colaboração fundada num contrato de redação explicito, apoiado por relaçóes de amizade e por um esforço de pesquisa de mais de trinta anos: "Davi Kopenawa me incumbiu de dar maior divulgação possível a suas palavras, através da escrita em uso em meu próprio mundo" (ALBERT, 2015, p. 536). Na escrita "um tanto experimental deste livro", o antropólogo Albert relata:

10 Antropólogo britânico cujo trabalho revelou-se determinante para o desenvolvimento da antropologia social no século XX, (1902-1973).

11 Para uma discussão dos modos de tradução "mais próxima" e "à meia distância", contrapostas a estratégias de elaboração literária mais distanciada, ver Lejeune (1980, pp. 290-300). 
Este livro, composto de relatos autobiográficos e reflexôes xamânicas, está escrito na primeira pessoa, a pessoa que com vigor e inspiração carrega a voz de Davi Kopenawa. No entanto, essa primeira pessoa contém assumidamente um duplo "eu". A fala que se faz ouvir no texto, resultante de um vasto corpus de gravações, é a de seu autor, transcrita com a maior fidelidade possível. Contudo, dada a sua pouca familiaridade com a escrita," o "eu" desta narrativa é também o de um outro, um alter ego redator - eu mesmo. De modo que este livro é afinal um "texto escrito/falado a dois". Trata-se de uma obra de colaboração na qual duas pessoas o autor das palavras transcritas (que precedem e transcendem sua transferência à escrita) e o autor da redação (que recompóe esta produção oral, fixada a um dado momento, para fazê-la texto) - empenham-se em ser um só (2015, p. 537).

A estratégia de redação adotada por Albert se apresenta como uma brecha nas convençôes da escrita etnográfica usual para dar a ouvir de modo mais direto a voz de Davi Kopenawa. Masde acordo com Spivak: "o processo de fala se caracteriza por uma posição discursiva, uma transaçáo entre o falante e ouvinte" e, nesse sentido, conclui a autora afirmando que "esse espaço dialógico de interação não se concretiza jamais para o sujeito subalterno ${ }^{12}$ que, desinvestido de qualquer forma de agenciamento, de fato, não pode falar" (2010, p. 13).

Sobre a fabricaçáo do texto, o trabalho de redação em francês de um depoimento oral táo rico e complexo quanto o de Davi Kopenawa, inteiramente feito em sua língua, se mostrou uma tarefa delicada e cheia de desafios. O redator está diante de um vasto e profuso pré-texto oral, ao mesmo tempo multifragmentado e proteiforme, produzido no bojo de um diálogo de longa duração.

É nesse imenso e buscar uma coerência e fazer surgir uma voz escrita. Segundo Albert: "caberá ao leitor julgar o resultado desta aventura narrativa e a pertinência das escolhas que a orientaram" (2015, p. 541).

O processo de construção dessa obra aqui apresentada se configura, conforme finaliza Albert: "em março de 2008 confirmei com Kopenawa, em longas sessōes de revisão conjunta em Watoriki, ${ }^{13}$ que estávamos perfeitamente de acordo quanto à sua versão final e às modalidades de sua publicação" (2010, p. 548).

Após essas últimas sessōes de trabalho o texto foi finalizado em francês, e enquadrado em um conjunto formado pelos 24 capítulos com duas "introduçóes" (meu prólogo e o de Davi Kopenawa, intitulado "Palavras dadas") e duas "conclusôes" (a de Davi Kopenawa, "Palavras de Omama", e meu "Postscriptum"), composto de 729 páginas (ALBERT, 2015, p. 548).

12 Para Spivak (2010, p. 12), o termo subalterno deve ser resgatado o significado que Gramsci lhe atribuiu ao se referir ao "proletariado", ou seja aquele que a voz náo pode ser ouvida. O termo subalterno descreve as camadas mais baixas da sociedade constituídas pelos modos específicos de exclusão do mercado, da representação política e legal, e da possibilidade de se tornarem membros plenos no estado social dominante.

13 Montanha do vento, região do nascimento de Davi Kopenawa. 


\section{CONSIDERAÇÕES FINAIS}

Diante das clivagens expostas referentes ao trabalho de mediação cultural, desenvolvidas pelo antropólogo Bruce Albert, na tradução, transcrição e ediçãao do livro a presentado como uma obra de coautoria entre o antropólogo Albert e Davi Kopenawa, A Queda do Céu: palavras de um xamã yanomami. Buscamos compreender se esse trabalho mediado por Albert reverberou de forma positiva, representando conquistas referentes as lutas travadas pelos indígenas no meio social, político e cultural. Derrubando os silêncios epistêmicos construídos e mantidos pela "colonialidade do saber" ${ }^{14}$ ou se esse produto cultural, reinterpretado, manipulado pelo antropólogo Albert no processo de mediaçáo cultural em sua nova significância se subverteu quando foi incorporado na cultura do tradutor, usurpando significados provenientes da cultura do qual o texto emergiu (ORDINE, 2009).

De acordo com Mignolo: "o discurso hegemônico (...) criou a ilusão de que o conhecimento é des-incorporado e des-localizado e que é necessário, em todas as regiōes do planeta, "subir à epistemologia da Modernidade" $(2003,2)$. Além disso, "a história universal é universal no enunciado, mas é local na enunciação (...), que está sempre localizada" (MIGNOLO, 2003, p. 4).

O corpo indígena pensa, sente e produz conhecimento desde outro lócus de anunciação, desse modo, é necessário se desprender do conhecimento geopoliticamente situado, mover-se para corpo-político do conhecimento que denuncia a pretendida universalidade de uma etnicidade particular (biopolítica), localizada em uma regiáo específica do planeta (geopolítica).

Obviamente, ao procurar o antropólogo Albert afim de poder escrever um livro que relatasse a história do povo Yanomami, Kopenawa explicita a dificuldade de falar e ser ouvido, assim recorre ao discurso hegemônico para fazê-lo. Spivak, "refere-se ao fato de a fala do subalterno e do colonizado ser sempre intermediada pela voz de outrem, que coloca em posição de reivindicar algo em nome de um(a) outro(o)" (2010, p. 14).Esse argumento destaca, acima de tudo, a ilusão e a cumplicidade do intelectual que o mesmo crê poder falar pelo outro(a).

14 A colonialidade do saber está inserida no conceito Colonialidade do poder, cunhado pelo peruano Aníbal Quijano, em 1989. O conceito de colonialidade foi estendido para outros âmbitos que não só o do poder. Assim, Mignolo $(2010,12)$ sugere que a matriz colonial do poder "é uma estrutura complexa de níveis entrelaçados", como: o controle da economia, da autoridade, natureza e dos recursos naturais, do gênero e da sexualidade, da subjetividade e do conhecimento. A colonialidade se reproduz em uma tripla dimensão: a do poder, do saber e do ser. Segundo Tirado $(2009$, 5), a teoria de Quijano sobre a colonialidade propóe uma concepção da diferenciaçáo colonial e epistêmica, na qual a colonialidade se transfere do âmbito do poder para o campo do saber, construindo a colonialidade do saber que age de forma a manter a hegemonia eurocêntrica como perspectiva superior do conhecimento. As ciências sociais se constroem neste espaço de dominação e são atravessadas por essas relaçóes de poder. O conhecimento se desenvolve dentro do espaço que lhe é "disponibilizado", e a partir da episteme "oferecida". Essa episteme está sustentada numa estrutura de poder que garante a hegemonia dos dominantes, ao mesmo tempo que deslegitima as manifestaçóes contra-hegemônicas. Desta forma, o conhecimento está organizado segundo os centros de poder e subordina as regiốes periféricas. 
Quando o antropólogo Albert busca dar voz a Kopenawa na primeira pessoa da narrativa do livro; por meio processo de tradução do Yanomami para o francês; ele reproduz as estruturas de poder e opressão, mantendo Kopenawa silenciado.

Ao desenvolver sua escrita experimental no processo de mediaçáo do livro A Queda do Céu, o antropólogo recorre a sua língua; o francês, postura essa que reafirma o caminho convencional que é o da escrita hegemônica, mesmo se utilizando de inovações metodológicas como relata Castro:

Invenção de uma narrativa etnográfica ao mesmo tempo poética e filosófica, crítica e reflexiva que desloca, inverte e renova o discurso da antropologia sobre os povos ameríndios, redefinindo suas condiçóes metodológicas e pragmáticas de enunciação (2015, p. 12).

O que temos é um produto cultural singular, no qual, mais uma vez, um antropólogo conta a história dos povos indígenas sob a perspectiva dominante. Assim, diante do exposto, a mediaçáo desenvolvida por Albert no projeto do livro náo inverteu os polos do discurso desigual em relação aos povos indígenas do Brasil.

Os povos indígenas escrevem sua história para o urgente fim do silenciamento, visto e reproduzido em muitas páginas da historiografia nacional. Nas quais a participação indígena é sistematicamente ocultada e inferiorizada.

A história indígena ensinada nas escolas perpetua o silenciamento epistêmico construído e mantido pela colonialidade do saber. Como afirmou (Cunha,1992), durante muito tempo os indígenas não foram vítimas apenas da eliminação física, mas também foram eliminados enquanto sujeitos históricos.

Como relata Kopenawa: "Antigamente, os brancos falavam de nós à nossa revelia e nossas verdadeiras palavras permaneciam escondidas na floresta. Ninguém, além de nós, podia escutá-las" (2015, p. 389). Escutar e entender as verdadeiras palavras que vem da floresta é uma forma de ruptura possível da subalternização do conhecimento indígena, de acordo com Spivak:

A tarefa do intelectual pós-colonial deve ser a de criar espaços por meio dos quais o sujeito subalterno possa falar para que, quando ele ou ela o faça, possa ser ouvido (a). Não se pode falar pelo subalterno, mas pode-se trabalhar "contra" a subalternidade, criando espaços nos quais o subalterno possa se articular e, como consequências, possa também ser ouvido (2010, p.14). 


\section{REFERÊNCIAS}

ALBERT, Bruce. Situation ethnographique et mouvements et hniques: Réflexionssur le terrain post malinowskien. In: AGIER, Michel (Org).Anthropoloques en danger. L' engagement sur le terrain. Paris: Jean-Michel Place, 1997.

ALMEIDA, Sandy Anne Czoupinski. Histórias de índio, de Daniel Munduruku, e Wills Garden, de Lee Maracle: afirmando a identidade indígena pela literatura. Monografia, Setor de Ciências Humanas, Letras e Artes da Universidade Federal do Paraná, Curitiba, 2008.

ALMEIDA, Sandra Regina G. Prefácio. In: SPIVAK, Gayatri Chakravorty. Pode o subalterno falar? Tradução de Sandra Regina Goulart Almeida, Marcos Pereira Feitosa, André Pereira Feitosa. Belo Horizonte, Editora da UFMG, 2010.

BANIWA, Gerson dos Santos Luciano. O Índio Brasileiro: o que você precisa saber sobre os povos indígenas no Brasil de hoje. Edições MEC/UNESCO. Brasília, novembro de 2006.

BURKE, Peter E R. Po-hsia HSIA (orgs). A tradução cultural nos primórdios da Europa moderna. Tradução de Roger Maioli dos Santos. São Paulo: Editora UNESP, 2009.

BRASIL, Constituição (1988). Constituição da República Federativa do Brasil de 1988. Disponível em: <http: //www.planalto.gov.br/ccivil_03/constituicao/ ConstituicaoCompilado.htm>. Acesso em: 28 abril.2017.

BRASIL, Decreto n.26, de 4 de fevereiro de 1991.Dispóe sobre a Educação Indígena no Brasil.1991. Disponível em: http://.planalto.gov.br/ccivil 03/decreto/1990-1994/D0026. htm. Acesso em 28 de abril. 2017.

BRASIL, Ministério da Educação. Referencial curricular nacional para as escolas indígenas. Brasília: MEC/SEF, 1998 a. Disponível em: http://www.ufpe.br/remdipe/imagens/ documentos/edu_escolar/ml_07.pdf. Acesso em 28 abril. 2017.

CARBONEL, O. The exotic space of Cultural Translation. In: ÁLVAREZ, R.; VIDAL, M. Carmem-África. Translation, Power and Subversion. London: Multilingual Matter LTD. pp. 79-98, 1996.

CASTRO, Eduardo Viveiro de. Prefácio. In: KOPENAWA, D.; ALBERT, B. A Queda do céu: palavras de um xamã Yanomami. ${ }^{\circ}$ ed., São Paulo: Companhia das Letras,2015.

CHAGNON, Napoleon. Yanomamö: The Fierce People. 1. ed., New York: Holt, Rinehart and Winston, Inc, 1968.

CHARTIER, Roger. A história cultural - entre práticas e representaçóes. Lisboa: Difel, 1987.

O mundo como representação. Estudos Avançados. São Paulo: USP, 11(5), pp.173-191,1991. 
CHARTIER, Roger. Á beira da falésia: a história entre incertezas e inquietudes. Trad. Patrícia Chittoni Ramos. Porto Alegre: Ed. Universidade/UFRGS, 2002.

CUNHA, M. C. (Orgs). História dos Índios no Brasil. São Paulo: Companhia da Letras, 1992.

FRANCA, Aline da Silva. Do Cocar ao Catálogo: a representação bibliográfica da autoria indígena no Brasil. Dissertação (mestrado). Programa de Pós-Graduação em Biblioteconomia, Universidade Federal do Estado do Rio de Janeiro, 2016.

GOMES, Ângela de Castro e HANSEN, Patricia Santos (org). Intelectuais Mediadores: práticas culturais e ação política. 1 ed., Rio de Janeiro: Civilização Brasileira, 2016.

KOPENAWA, D.; ALBERT, B.A Queda do céu: palavras de um xamã Yanomami.1ºd., São Paulo: Companhia das Letras, 2015.

LANDER, Edgardo (org). A colonialidade do saber: eurocentrismo e ciências sociais Perspectivas latino-americanas. ColecciónSurSur, CLACSO, Cuidad Autónoma de Bueno Aires-Argentina, setembro, 2005.

LEJEUNE, Philippe. Je est unautre: L'autobiographie, de lalittératureaux médias. Paris: Seuil. (Coleção Poétique),1980.

LEOPOLDI, José Sávio. Rousseau - estado de natureza, o "bom selvagem” e as sociedades indígenas. Alceu. Rio de Janeiro: Editora PUC-Rio, v.2, n.4, p. 158-172, jan./jun. 2002. Disponível em: <HTTP:/REVISTAALCEU.COM.PUC-RIO.BR/CGI/CGILUA.EXE/SYS/START.HTM?SID=I9>. Acesso em: 2017-08-29.

MARTÍN, Jesús Barbero. Dos meios ás mediaçôes: comunicação, cultura e hegemonia. Tradução de Ronaldo Polito e Sérgio Alcides. Rio de Janeiro: Editora UFRJ, 1997.

. As formas mestiças da mídia. Entrevista concedida à Mariluce Moura. Pesquisa FAPESP Online. São Paulo: Edição 163, p. 10-15, set. 2009. Disponível em: <http://revistapesquisa.fapesp.br/2009/09/01/as-formas-mesticas-da-midia/>. Acesso em: 28 ago. 2017.

MARTINS, Andrea Castelaci. A temática indígena na literatura infantil e juvenil - um percurso. Literartes, São Paulo, n. 5, p. 120-149, oct. 2016. ISSN 2316-9826. Disponível em: <https://www.revistas.usp.br/literartes/article/view/112222>. Acesso em: 30ago. 2017.

MIGNOLO, D. Walter. Histórias locais / Projetos globais: colonialidade, saberes subalternos e pensamento liminar. Tradução de Solange Ribeiro de Oliveira. Belo Horizonte: Editora da UFMG, 2003.

La opción De-colonial: Desprendimiento y Apertura. Um Manifiesto y Un Caso. Duke University, Durham, p. 245-281, USA, 2008.

Desobediencia epistémica: retórica de la modernidad, lógica de la colonialidad y gramática de la descolonialidad. Argentina: Edicionesdel signo, 2010.

MUNDURUKU, Daniel. Todas as coisas são pequenas. São Paulo: Arx, 2008. 
OLIVEIRA, Manoela Freire de. Significaçóes Históricas do Índio: Leituras da Mídia Impressa e da Literatura. (2005). Dissertação (Mestrado), Programa de Pós-Graduação em Letras e Linguística, Instituto de Letras, Universidade Federal da Bahia (UFBA), Salvador, 2005. Disponível em: <http://www.repositorio.ufba.br/ri/handle/ri/10830>.Acesso em: 02 de jul.2017.

ORDINE, Rodrigo. A tradução cultural de Aké. DARANDINA revist eletronica- UFJF. Comunicação do Simpósio internacional Literatura, crítica, cultura III: Interfaces, 2009.

PEREIRA, Maira Luiza Scher. O tema do índio e a consciência de nossa diferença. Revista Brasil de Literatura. Ano IV, 2002. Disponível em: <http://lfilipe.tripod.com/indio.htm>. Acesso em: 05 de ago. 2017.

PESAVENTO, Sandra Jatahy. História \& História Cultural. 2o ed, Belo Horizonte: Autêntica, 2005.

RONSINI, Veneza V. Mayora. A perspectiva das mediações de Jesús Martin-Barbero. XIX Encontro da Compós, PUC-RJ. Rio de Janeiro, junho de 2010, pp. 1-16. Disponível em: <compos.com.puc-rio.br/media/gt12_veneza_ronsini.pdf>. Acesso em: 02 de ago. 2017.

SAID, Edward. Orientalism. New York: Vintage, 1979.

SPIVAK, Gayatri Chakravorty. Pode o subalterno falar? Tradução de Sandra Goulart Almeida, Marcos Pereira Feitosa, André Pereira Feitosa. Belo Horizonte, Editora da UFMG, 2010 .

STYCER, Mauricio. Padilha expóe guerra entre antropólogos por causa dos Yanomami. Disponível em:<http://cinema.uol.com.br/ultnot/2010/04/08/padilha-expoe-guerra-entre -antropologos-por-causa-dos-ianomami.jhtm>. Acesso em: 22 de jun. 2016.

TIERNEY, Patrick. Trevas no eldorado: como os cientistas e jornalistas devastaram a Amazônia. Rio de Janeiro: Ediouro, 2002.

Yanomami: um povo ameaçado. Reportagens - Amazônia: interesses e conflitos. Disponível em: <http://www.comciencia.br/reportagens/amazonia/amaz10.htm>. Acesso em: 17 jun. 2016.

TIRADO, Genara Pulido. Violencia Epistémica y Descolonizacón del Conocimiento. Sociocriticism, vol. 24, no . 1-2, pp. 173-201, 2009. Disponível em: <https://dialnet.unirioja.es/revista/19997/V/24>. Acesso em: 10 jun.2016. 